REPORTS OF MORPHOLOGY
$\begin{gathered}\text { Official Journal of the Scientific Society of Anatomists, } \\ \text { Histologists, Embryologists and Topographic Anatomists } \\ \text { of Ukraine } \\ \text { journal homepage: https://morphology-journal.com }\end{gathered}$

\title{
Morphometric characteristics of skull and face parameters in fetuses and newborns
}

Slobodian O.M., Kostyuk V.O., Dundiuk-Berezyna S.I.

Bukovinian State Medical University, Chernivtsi, Ukraine

\section{ARTICLE INFO}

Received: 25 February 2021

Accepted: 14 April 2021

UDC: $611.714 .06-053.15-053.31$

\section{CORRESPONDING AUTHOR}

e-mail: slobodyanaleksandr@ukr.net Slobodian O.M.
Modern science has a significant number of diagnostic methods: craniological, anatomical, ultrasound, radiological. The development of new research methods, such as ultrasound and $X$-ray methods (magnetic resonance imaging), forms the concept of ultrasound and X-ray norms at different stages of human development. Now it is important to study the anatomical variability of people, morphometric characteristics, relationships of organs, anatomical structures, their parts at all stages of human development. The purpose of the work is to establish normative morphometric parameters of the skull and face in fetuses and newborns, followed by construction of mathematical models. The study was performed on 57 preparations of human fetuses 4-10 months and 7 newborns using adequate anatomical methods: macropreparation, topographic anatomical sections, computed tomography, craniometry. The main parameters of the facial and cerebral skull were measured with the help of a centimeter tape, a thick, sliding compass and a caliper. Statistical analysis of the obtained data was performed using a licensed program RStudio. It is established that according to the graphs of the average values of the parameters of the skull and face, there are two periods of accelerated and two periods of slow development. For transverse skull length, face width and skull height, two periods of accelerated development from the 6 th to the 8th month of fetal development and from the 9th month of fetal development to the neonatal period and two periods of delayed development from the 5th to the 6th months and from the 8th to the 9th month of fetal development were revealed. For the total height of the face - periods of accelerated development - from the 4th to the 6th month of fetal development and from the 7 th to the 9th month of fetal development, periods of delayed development - from the 6th to the 7th month of fetal development and from the 9th month of fetal development to the neonatal period. On the basis of arithmetic mean data of transverse skull length, face width, skull height, total face height, models for predicting normative morphometric parameters in fetuses and newborns are constructed. The constructed models will serve as a norm for the subsequent determination of certain morphometric deviations to establish variants of the structure and malformations of the skull and face. Thus, our systematized data on the features of spatio-temporal transformations of morphometric parameters of transverse skull length, face width, skull height, total face height with subsequent construction of mathematical models will contribute to the individualization of the norm, improvement of early diagnosis methods and development of new methods for surgical correction of congenital defects of the skull and face.

Keywords: skull, morphometry, fetus, newborn, human.

\section{Introduction}

Congenital malformations of the maxillofacial area rank third among other congenital anomalies. $70 \%$ of them are congenital nonunion of the upper lip and palate, and $30 \%$ - craniofacial dysostosis [15, 18]. The most diverse are congenital malformations of the upper and lower jaws, which are expressed in deviations from the norm of their size, shape, position of the jaws and changes in syntopia (agnathia, micro- and macrognathia, prognathia, nonunion of the upper jaw and palate) [4, 10, 13, 20].

The severity of malformations of the face is manifested not only by external ugliness and the severity of functional disorders, but also negatively affects the mental 
development of the child $[6,12,16]$.

Modern science has a significant number of diagnostic methods: craniological, anatomical, ultrasound, radiological. The development of new research methods, such as ultrasound and X-ray methods (magnetic resonance imaging), forms the concept of ultrasound and X-ray norms at different stages of human development [2, 7]. Nowadays it is important to study the anatomical variability of man, morphometric characteristics, relationships of organs, anatomical structures, their parts at all stages of human development, the study of bone formations of the skull: foramens, fissures, channels [3, 9, 5, 17]. It is also important to predict the state of the structures located in these formations, their possible causes and consequences, for example, compression lesions [9, 11].

The purpose of the work is to establish normative morphometric parameters of the skull and face in fetuses and newborns, followed by construction of mathematical models.

\section{Materials and methods}

The study was performed on 57 preparations of human fetuses 4-10 months and 7 newborns (including 5 isolated organ complexes) of both sexes, without external signs of anatomical abnormalities or anomalies and without obvious macroscopic deviations from the normal structure of the skull using adequate anatomical methods: macropreparation, topography sections, computed tomography, craniometry. The craniometric study was performed in the horizontal ear-eye plane, in the so-called "Frankfurt horizontal". Prior to that, each object was fixed in a craniostat. Using a centimeter tape, a thick, sliding compass and a caliper, the main parameters of the facial and cerebral skull were measured: skull height, transverse skull length, total face height, face width.

The work was performed in compliance with the main provisions of the Helsinki Declaration of the World Medical Association on ethical principles of scientific medical research with human participation (1964-2000) and the order of the Ministry of Health of Ukraine №690 from 23.09.2009 and is a fragment of comprehensive planned initiative research work of departments human anatomy named after M.G. Turkevich, anatomy, clinical anatomy and operative surgery of Bukovynian State Medical University of the Ministry of Health of Ukraine: "Regularities of sex-age structure and topographic-anatomical transformations of organs and structures of the organism at pre- and postnatal stages of ontogenesis. Peculiarities of perinatal anatomy and embryotopography", state registration number $0120 \mathrm{U} 101571$.

Statistical analysis of the obtained data was performed using a licensed program RStudio. We tested the null hypothesis that the samples were taken from one distribution, or from distributions with the same medians:

$\mathrm{H}_{0}$ : :each group has the same distribution\}

$\mathrm{H}_{1}$ : \{each group does not have the same distribution\}

We used the Student's test, the non-parametric KruskalWallis test (answers the question of whether there is a difference between group distributions, but does not specify which groups differ), the Conover-Iman test to compare stochastic dominance and obtain results between different pairwise comparisons after the Kruskal-Wallis test for stochastic dominance among groups. The values at $p<0.05$ were considered statistically significant.

Evaluated the nature of the distributions for each of the obtained variation series, averages for each trait studied, the standard deviation, the percentile range of indicators.

\section{Results}

Analyzing the morphometric parameters of the transverse length of the skull in fetuses and newborns by constructing a box diagram (Fig. 1), we can state that the difference between the medians of the samples (horizontal line in the box) is significantly statistically significant. The Kruskal-Wallis test gave the following results: since $p<0.05$, the difference between the medians of the groups is statistically significant. Using the Conover-Iman test, comparing the morphometric parameters of the transverse length of the skull by age groups found that for all possible pairs the median difference is statistically significant, except for pairs " 5 months - 6 months", "8 months - 9 months", "9 months - 10 months" and "10 months - Newborns".

The described statistical parameters of the transverse length of the skull in fetuses and newborns (Table 1), prove that there is a significant (statistically significant) difference between the averages for all groups, except for pairs "5 months - 6 months", "7 months - 8 months", "8 months - 9 months", "9 months - 10 months" and "10 months Newborns".

The graph of the average values of the transverse length of the skull in fetuses and newborns (Fig. 2) indicates the intensity of transformations of these parameters.

After analyzing the morphometric parameters of facial width in fetuses and newborns, a box diagram was constructed (Fig. 3), on which we observe the difference between the medians of the samples (horizontal line in the box), which is statistically significant.

The Kruskal-Wallis test gave the following results: since

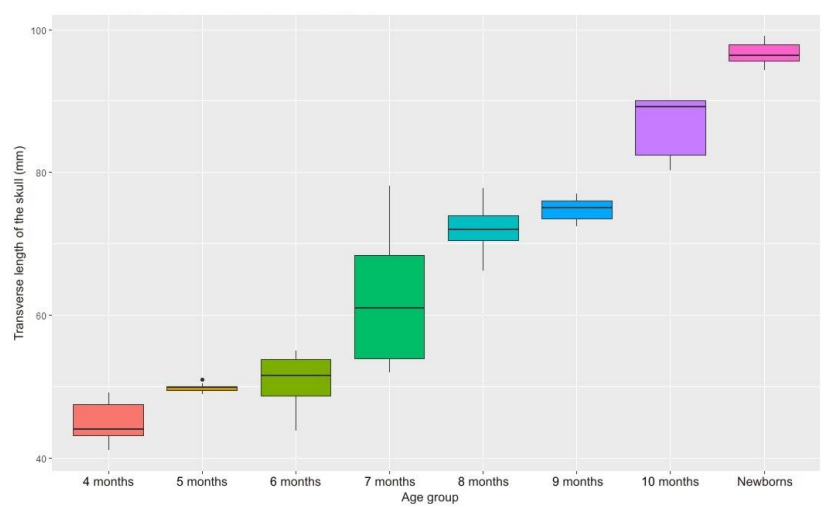

Fig. 1. Box diagram of the transverse length of the skull in fetuses and newborns $(\mathrm{mm})$. 
Table 1. Statistical indicators of transverse skull length in fetuses and newborns $(\mathrm{mm})$.

\begin{tabular}{|c|c|c|c|}
\hline Age group & Average & $\begin{array}{c}\text { Standard error for } \\
\text { average }\end{array}$ & $\begin{array}{c}\text { Confidence interval for } \\
\text { the average }\end{array}$ \\
\hline 4 months & 45.13 & 1.17 & $(42.28 ; 47.98)$ \\
\hline 5 months & 49.86 & 0.17 & $(49.47 ; 50.25)$ \\
\hline 6 months & 50.98 & 1.01 & $(48.75 ; 53.21)$ \\
\hline 7 months & 62.01 & 2.78 & $(55.82 ; 68.20)$ \\
\hline 8 months & 72.10 & 1.60 & $(67.98 ; 76.22)$ \\
\hline 9 months & 74.78 & 0.83 & $(72.48 ; 77.08)$ \\
\hline 10 months & 86.42 & 2.10 & $(80.58 ; 92.26)$ \\
\hline Newborns & 96.69 & 0.64 & $(95.12 ; 98.26)$ \\
\hline
\end{tabular}

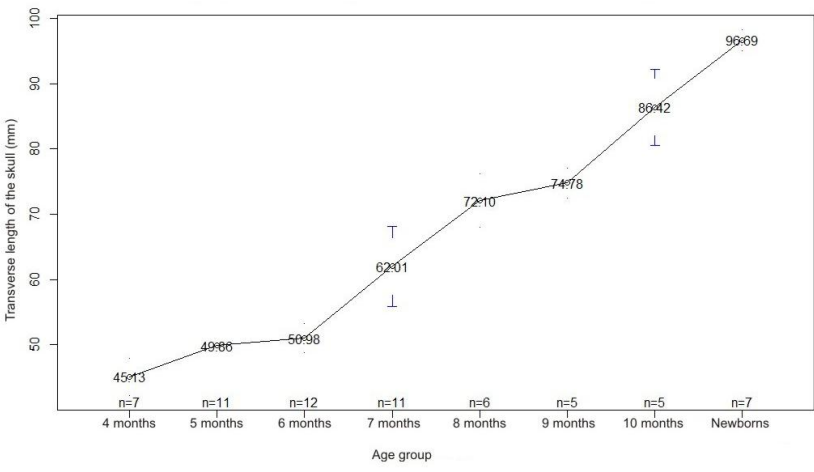

Fig. 2. Graph of mean values of transverse skull length in fetuses and newborns $(\mathrm{mm})$.

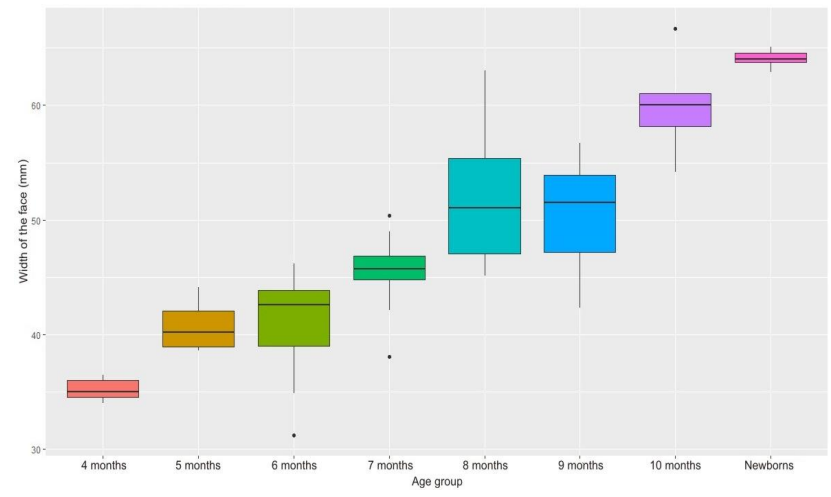

Fig. 3. Box diagram of the width of the face in fetuses and newborns (mm).

$p<0.05$, the difference between the medians of the groups is statistically significant. Using the Conover-Iman test, comparing the morphometric parameters of facial width by age groups, he found that for all possible pairs the median difference is statistically significant, except for the pairs " 5 months - 6 months", "7 months - 9 months", "8 months - 9 months" and "10 months - Newborns".

The described statistical parameters of facial width in fetuses and newborns (Table 2) prove that there is a significant (statistically significant) difference between the averages for all groups, except for pairs "5 months - 6 months", "6 months - 7 months", "6 months - 9 months", "7 months - 8 months", "7 months - 9 months", "9 months - 10
Table 2. Statistical indicators of facial width in fetuses and newborns (mm).

\begin{tabular}{|c|c|c|c|}
\hline Age group & Average & $\begin{array}{c}\text { Standard error for } \\
\text { average }\end{array}$ & $\begin{array}{c}\text { Confidence interval for } \\
\text { the average }\end{array}$ \\
\hline 4 months & 35.23 & 0.37 & $(34.34 ; 36.12)$ \\
\hline 5 months & 40.80 & 0.62 & $(39.43 ; 42.17)$ \\
\hline 6 months & 41.04 & 1.28 & $(38.23 ; 43.85)$ \\
\hline 7 months & 45.46 & 0.99 & $(43.25 ; 47.67)$ \\
\hline 8 months & 52.12 & 2.75 & $(45.04 ; 59.20)$ \\
\hline 9 months & 50.32 & 2.54 & $(43.27 ; 57.37)$ \\
\hline 10 months & 60.02 & 2.03 & $(54.37 ; 65.67)$ \\
\hline Newborns & 64.09 & 0.29 & $(63.37 ; 64.81)$ \\
\hline
\end{tabular}

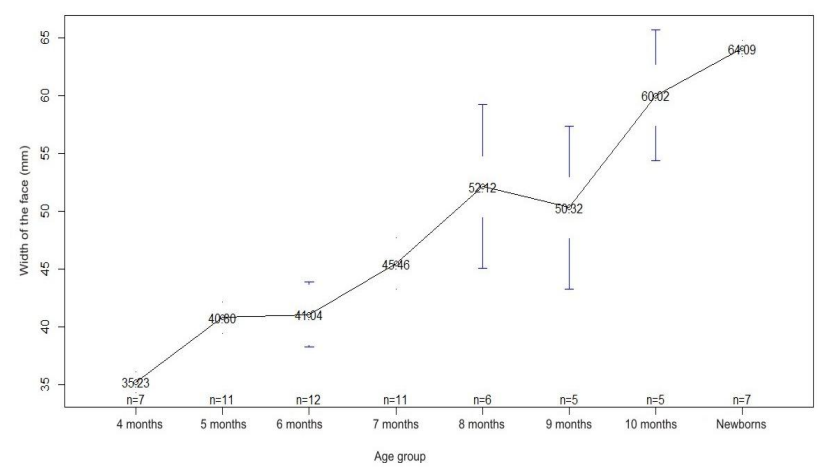

Fig. 4. Graph of average values of facial width in fetuses and newborns $(\mathrm{mm})$.

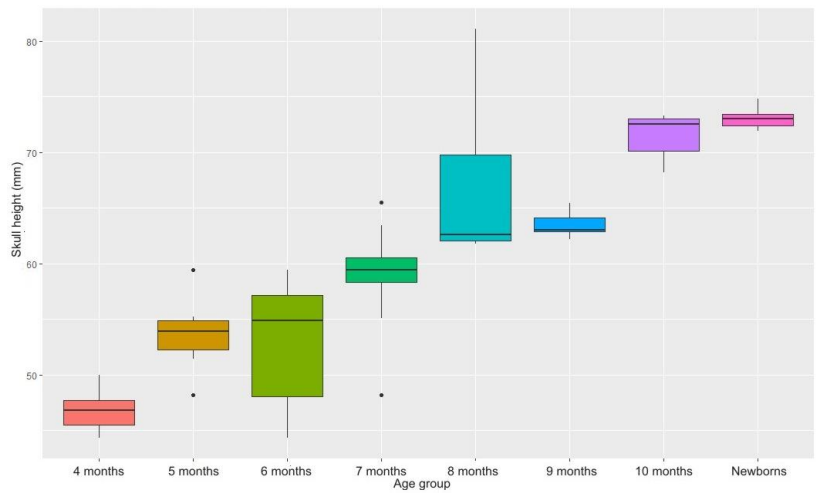

Fig. 5. Box diagram of skull height in fetuses and newborns ( $\mathrm{mm})$.

months" and "10 months - Newborns".

The graph of the average values of facial width in fetuses and newborns (Fig. 4) indicates the intensity of transformations of these parameters.

Analyzing the morphometric parameters of skull height in fetuses and newborns by constructing a box diagram (Fig. 5), we can observe the difference between the medians of the samples (horizontal line in the box), which is significantly statistically significant. The Kruskal-Wallis test gave the following results: since $p<0.05$, the difference between the medians of the groups is statistically significant. Using the Conover-Iman test, comparing the morphometric parameters of skull height by age groups found that for all 
Table 3. Statistical indicators of skull height in fetuses and newborns $(\mathrm{mm})$.

\begin{tabular}{|c|c|c|c|}
\hline Age group & Average & $\begin{array}{c}\text { Standard error for } \\
\text { average }\end{array}$ & $\begin{array}{c}\text { Confidence interval for } \\
\text { the average }\end{array}$ \\
\hline 4 months & 46.79 & 0.74 & $(44.98 ; 48.60)$ \\
\hline 5 months & 53.66 & 0.85 & $(51.77 ; 55.55)$ \\
\hline 6 months & 53.15 & 1.55 & $(49.74 ; 56.56)$ \\
\hline 7 months & 58.95 & 1.35 & $(55.94 ; 61.96)$ \\
\hline 8 months & 67.02 & 3.24 & $(58.69 ; 75.35)$ \\
\hline 9 months & 63.52 & 0.56 & $(61.97 ; 65.07)$ \\
\hline 10 months & 71.42 & 0.98 & $(68.69 ; 74.15)$ \\
\hline Newborns & 73.04 & 0.38 & $(72.11 ; 73.97)$ \\
\hline
\end{tabular}

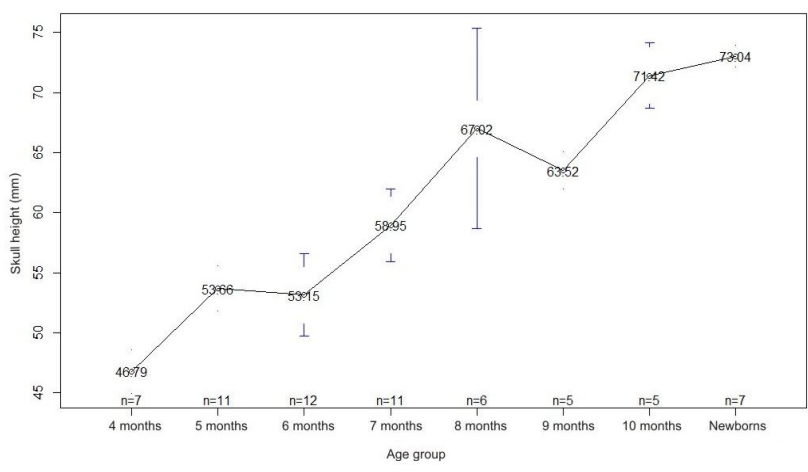

Fig. 6. Graph of mean values of skull height in fetuses and newborns $(\mathrm{mm})$.

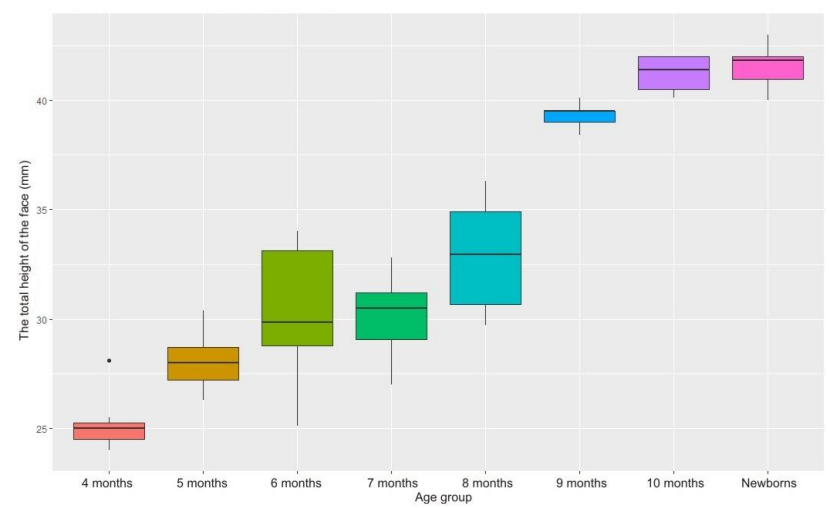

Fig. 7. Box diagram of the total height of the face in fetuses and newborns $(\mathrm{mm})$.

possible pairs the median difference is statistically significant, except for pairs "5 months - 6 months", "8 months - 9 months", "9 months - 10 months", "8 months - 10 months" and "10 months - Newborns".

The determined statistical parameters of skull height in fetuses and newborns (Table 3) prove that there is a significant (statistically significant) difference between the averages for all groups, except for pairs " 5 months - 6 months", "6 months - 7 months", "7 months - 8 months", "8 months - 9 months", " 8 months - 10 months" and "10 months - Newborns".

The graph of average values of skull height in fetuses and newborns (Fig. 6) indicates the intensity of transformations of these parameters.

The analysis of morphometric parameters of the total face height in fetuses and newborns by constructing a box diagram (Fig. 7) shows that the difference between the medians of the samples (horizontal line in the box) is statistically significant. The Kruskal-Wallis test gave the following results: since $p<0.05$, the difference between the medians of the groups is statistically significant. Using the Conover-Iman test, comparing the morphometric parameters of the total height of the face by age groups found that for all possible pairs the median difference is statistically significant, except for pairs " 5 months - 6 months", "9 months - 10 months", "9 months - Newborns" and "10 months - Newborns".

The described statistical parameters of the total face height in fetuses and newborns (Table 4), prove that there is a significant (statistically significant) difference between the averages for all groups, except for pairs " 5 months - 6 months", "5 months - 7 months", "6 months - 7 months", "6 months - 8 months", "7 months - 8 months", and "10 months - Newborns".

The graph of the average values of the total height of the face in fetuses and newborns (Fig. 8) indicates the intensity of transformations of these parameters.

After correlating all morphometric parameters of the skull and face of fetuses and newborns using Pearson's correlation coefficient, it was found that between the values

Table 4. Statistical indicators of the total height of the face in fetuses and newborns (mm).

\begin{tabular}{|c|c|c|c|}
\hline Age group & Average & $\begin{array}{c}\text { Standard error for } \\
\text { average }\end{array}$ & $\begin{array}{c}\text { Confidence interval for } \\
\text { the average }\end{array}$ \\
\hline 4 months & 25.23 & 0.52 & $(23.96 ; 26.50)$ \\
\hline 5 months & 28.03 & 0.38 & $(27.17 ; 28.89)$ \\
\hline 6 months & 30.39 & 0.81 & $(28.60 ; 32.18)$ \\
\hline 7 months & 30.03 & 0.55 & $(28.80 ; 31.26)$ \\
\hline 8 months & 32.90 & 1.11 & $(30.04 ; 35.76)$ \\
\hline 9 months & 39.30 & 0.28 & $(38.51 ; 40.09)$ \\
\hline 10 months & 41.20 & 0.39 & $(40.12 ; 42.28)$ \\
\hline Newborns & 41.53 & 0.39 & $(40.58 ; 42.48)$ \\
\hline
\end{tabular}

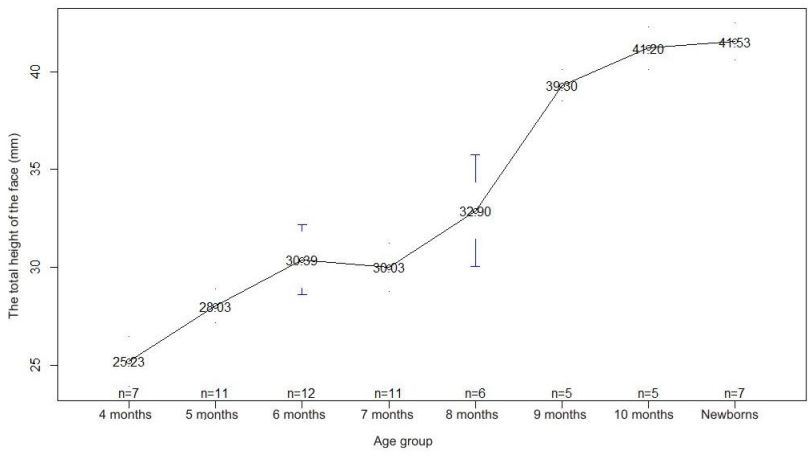

Fig. 8. Graph of average values of total face height in fetuses and newborns $(\mathrm{mm})$. 
of all paired correlation coefficients are positive and quite close to 1 (>0.90), which indicates a close strong positive correlation relationship between all morphometric parameters.

Comparing the mean values of all morphometric parameters of transverse skull length, face width, skull height, total face height in all age groups using the Wilcoxon test, it can be stated that all $p$-values are greater than the significance level $\alpha=0.05$, which means no significant difference. Thus, based on the arithmetic mean of transverse skull length, face width, skull height, total face height, models for predicting normative morphometric parameters in fetuses and newborns were constructed using fetal age and crownheel length.

The model of the transverse length of the skull in fetuses and newborns has the form:

Transverse length of the skull $=\beta_{0}+0.224 \times$ crown-heel length of the fetus,

where $\beta_{0}: 3.412$, if age period $=4$ months; $1.399=5$ months; $11.11=6$ months; $10.92=7$ months; $13.49=8$ months; $21.44=9$ months; $19.87=10$ months; $15.20=$ Newborns.

The coefficient of determination of the model is $96.34 \%$.

The model of the width of the face in fetuses and newborns has the form:

Face width $=\beta_{0}+0.071 \times$ crown-heel length of the fetus,

where $\beta_{0}: 22.00$, if age period $=4$ months; $24.54=5$ months; $21.35=6$ months; $22.34=7$ months; $24.98=8$ months; $19.81=9$ months; $26.32=10$ months; $28.61=$ Newborns.

The coefficient of determination of the model is $86.84 \%$. The model of skull height in fetuses and newborns has the form:

Skull height $=\beta_{0}+0.030 \times$ crown-heel length of the fetus, where $\beta_{0}: 41.27$, if age period $=4$ months; $46.88=5$ months; $44.94=6$ months; $49.30=7$ months; $55.69=8$ months; $50.79=9$ months; $57.36=10$ months; $58.24=$ Newborns.

The coefficient of determination of the model is $82.19 \%$.

The model of the total height of the face in fetuses and newborns has the form: fetus,

Total face height $=\beta_{0}+0.021 \times$ crown-heel length of the

where $\beta_{0}: 21.28$, if age period $=4$ months; $23.18=5$ months; $24.52=6$ months; $23.13=7$ months; $24.80=8$ months; $30.19=9$ months; $31.14=10$ months; $30.94=$ Newborns.

The coefficient of determination of the model is $90,85 \%$.

\section{Discussion}

Comparing the graphs of the average values of transverse skull length, facial width, skull height, facial height in fetuses and newborns, it should be noted that these parameters are characterized by non-synchronicity of their changes, they are characterized by periods of accelerated and slow increase. According to the graphs of the average values of these parameters, we can say that there are two periods of accelerated and slow development. For transverse skull length, face width and skull height, two periods of accelerated development from the 6th to the 8th month of fetal development and from the 9th month of development to the neonatal period and two periods of delayed development from the 5th to the 6th months and from the 8th to the 9th month of fetal development were revealed. Regarding the total height of the face, periods of accelerated development - from the 4th to the 6th month of development and from the 7 th to the 9th month of fetal development, periods of delayed development - from the 6th to the 7th month of development and from the 9th of fetal development to the neonatal period. Analyzing the data of the Conover-Iman test on statistically significant medians of the studied parameters of the skull and face, we can conclude that the pair "10 months Newborns" is unlikely for transverse skull length, face width, skull height, total face height. In our opinion, this is justified by the fact that each person has an individual anatomical variability [16].

The constructed models will serve as a norm for the subsequent determination of certain morphometric deviations for the establishment of variants of the structure and defects of the development of the skull and face $[1,8,14]$.

\section{Conclusions}

1. During the fetal period of ontogenesis and in the neonatal period, the transverse length of the skull increases from $45.13 \pm 1.17 \mathrm{~mm}$ in fetuses of the 4 th month to $96.69 \pm 0.64 \mathrm{~mm}$ in newborns, the width of the face - from $35.23 \pm 0.37 \mathrm{~mm}$ to $64.09 \pm 0.29 \mathrm{~mm}$, skull height - from $46.79 \pm 0.74 \mathrm{~mm}$ to $73.04 \pm 0.38 \mathrm{~mm}$, total face height - from $25.23 \pm 0.52 \mathrm{~mm}$ to $41.53 \pm 0.39 \mathrm{~mm}$, respectively.

2. According to the graphs of the average values of the parameters of the skull and face, there are two periods of accelerated and two periods of slow development. For the transverse length of the skull, the width of the face and the height of the skull, two periods of accelerated development were revealed: from the 6 th to the 8 th month of fetal development and from the 9th month of fetal development to the neonatal period and two periods of delayed development: from the 5th to the 6th month and from the 8th to the 9th month of fetal development. Regarding the total height of the face, periods of accelerated development - from the 4th to the 6th month of development and from the 7th to the 9th month of fetal development, periods of delayed development - from the 6 th to the 7th month of development and from the 9th to the of fetal development to the neonatal period.

3. On the basis of arithmetic mean data of transverse skull length, face width, skull height, total face height, models for predicting normative morphometric parameters in fetuses and newborns are constructed. Systematized data on the features of spatio-temporal transformations of morphometric parameters of transverse skull length, facial width, skull height, total facial height with their subsequent construction of mathematical models will contribute to the 
individualization of the norm, improvement of early diagnosis methods and development of new methods of surgical

\section{References}

[1] Bahsi, I., Orhan, M., Kervancioglu, P., \& Yalcin, E.D. (2019). Morphometric evaluation and surgical implications of the infraorbital groove, canal and foramen on cone-beam computed tomography and a review of literature. Folia Morphologica, 78(2), 331-343. doi: 10.5603/FM.a2018.0084

[2] Bertoglio, B., Corradin, S., Cappella, A., Mazzarelli, D., BiehlerGomez, L., Messina, C., ... Cattaneo, C. (2020). Pitfalls of Computed Tomography 3D Reconstruction Models in Cranial Nonmetric Analysis. Journal of Forensic Sciences, 65(6), 20982107. doi: 10.1111/1556-4029.14535

[3] Borghei-Razavi, H., Raghavan, A., Eguiluz-Melendez, A., Joshi, K., Fernandez-Miranda, J.C., Kshettry, V.R., \& Recinos, P.F. (2020). Anatomical variations in the location of veins draining into the anterior superior sagittal sinus: implications for the transbasal approach. Operative Neurosurgery, 18(6), 668-675. doi: $10.1093 / o n s / o p z 339$

[4] Constantine, S., Kiermeier, A., \& Anderson, P. (2020). The Normal fetal cephalic Index in the second and third trimesters of pregnancy. Ultrasound Quarterly, 36(3), 255-262. doi: 10.1097/ RUQ.0000000000000444

[5] Dmytrenko, R.R., Tsyhykalo, O.V., \& Honcharenko, V.A. (2020). Особливості морфогенезу кісток основи черепа у ранньому періоді онтогенезу людини [Features of morphogenesis of skull base bones in the early period of human ontogenesis]. Буковинський медичний вісник - Bukovynian Medical Bulletin, 24(3 (95)), 22-27. doi: 10.24061/2413-0737. XXIV.3.95.2020.67

[6] Dursun, A., Ozturk, K., \& Albay, S. (2018). Development of hard and soft palate during the fetal period and hard palate asymmetry. Journal of Craniofacial Surgery, 29(8), 2358-2362. doi: $10.1097 /$ SCS. 0000000000005016

[7] Grill, F.D., Behr, A.V., Rau, A., Ritschl, L.M., Roth, M., Bauer, F.X. ... Loeffelbein, D.J. (2019). Prenatal intrauterine maxillary development - An evaluation with three-dimensional ultrasound. Journal of Cranio-Maxillofacial Surgery, 47(7), 1077-1082. doi: 10.1016/j.jcms.2019.01.029

[8] Grzonkowska, M., Baumgart, M., Badura, M., Wisniewski, M., \& Szpinda, M. (2020). Morphometric study of the primary ossification center of the frontal squama in the human fetus. Surgical and Radiologic Anatomy, 42(7), 733-740. doi: 10.1007/ s00276-020-02425-7

[9] Hizay, A., \& Sindel, M. (2019). Metoptic Canal and Warwick's Foramen: Incidence and Morphometric Analysis by Several Reference Points in the Human Orbit. The Eurasian Journal of Medicine, 51(1), 1-4. doi: 10.5152/eurasianjmed.2018.17353

[10] Horbatiuk, O.M., Makedonskyi, I.O., \& Kurylo, H.V. (2019). Cyчасні стратегії діагностики, хірургічної корекції та профрілактики вроджених вад розвитку у новонароджених [Modern strategies for diagnosis, surgical correction and prevention of congenital malformations in newborns]. Неонатологія, хірургія та перинатальна медицина - Neonatology, Surgery and Perinatal Medicine, 9(4), 88-97. doi: 10.24061/24134260.IX.4.34.2019.10

[11] Katsube, M., Rolfe, S.M., Bortolussi, S.R., Yamaguchi, Y., Richman, J.M., Yamada, S., \& Vora, S.R. (2019). Analysis of facial skeletal asymmetry during foetal development using $\mu \mathrm{CT}$ imaging. correction of congenital malformations.

Orthodontics \& Craniofacial Research, 22(1), 199-206. doi: 10.1111/ocr.12304

[12] Khmara, T.V., Ryznychuk, M.O., Kuzniak, N.B., Melnychuk, S.P., Batranovska, S.O., \& Zamorskyi, I.I. (2021). Онтологія варіантів будови та вад розвитку черепа. Частина II. Спадкові синдроми [Ontology of variants of structure and defects of skull development. Part II. Hereditary syndromes]. Український журнал медицини, біології та спорту - Ukrainian Journal of Medicine, Biology and Sports, 6(3), 71-77. doi: 10.26693/ jmbs06.03.071

[13] Korchynska, N.S., Slobodian, O.M., \& Kostyuk, V.O. (2019). Fetal anatomy of the maxillary cellular process. Клінічна анатомія та оперативна хірургія - Clinical Anatomy and Operative Surgery, 18(1), 62-66. doi: 10.24061/17270847.18.1.2019.10

[14] Marchenko, A.V., Petrushanko, T.O., \& Gunas, I.V. (2017). Moделювання за допомогою регресійного аналізу трансверзальних розмірів верхньої й нижньої щелепи та сагітальних характеристик зубної дуги в юнаків в залежності від особливостей донтометричних і кефралометричних показників [Simulation using regression analysis transversal sizes of upper and lower jaw and sagittal performance of dental arch in young depending on the characteristics of odontometric and cephalometric indicators]. Вісник морфоологіï - Reports of Morphology, 23(1), 107-111.

[15] Ng, A.F., Quintero, R.B., Lahirish, I.A.M., Holanda, V., Neto, M.R., \& De Oliveira, E. (2020). Microsurgical Anatomy Review of Bifrontal Limited Transbasal Approach-Quantitative and Anatomy Study. World Neurosurgery, 141, e1-e8. doi: 10.1016/ j.wneu.2020.02.114

[16] Rawhani, R., Abdellatif, A., Abushama, M., \& Ahmed, B. (2018). Antenatal diagnosis of fetal skeletal malformation. Donald School Journal of Ultrasound in Obstetrics and Gynecology, 12(2), 116-123. doi: 10.5005/jp-journals-10009-1561

[17] Slobodian, O.M., Kuzniak, N.B., \& Lavriv, L.P. (2016). Закономірності перинатальних органометричних параметрів ділянок і структур голови [Regularities of perinatal organometric parameters of areas and structures of the head]. Вісник проблем біології і медицини - Bulletin of Problems of Biology and Medicine, (2 (2)), 314-317.

[18] Slobodian, O.M., Proniaiev, D.V., \& Tovkach, Yu.V. (2020). Анатомо-функціональні особливості окремих структур та органів голови [Anatomical and functional features of individual structures and organs of the head]. Чернівці. БДМУ - Chernivtsi. BSMU.

[19] Vovk, Yu.M., Vovk, O.Yu. (2019). Індивідуальні анатомічна мінливість таїх клініко-морфологічне значення [Individual anatomical variability and their clinical and morphological significance]. Харків: ФОП Бронін О.В. - Kharkiv: FOP Bronin O.V.

[20] Zhang, Y., Ji, D., Li, L., Yang, S., Zhang, H., \& Duan, X. (2019). CIC-7 Regulates the pattern and early development of craniofacial bone and tooth. Theranostics, 9(5), 1387-1400. doi: 10.7150/thno.29761

\section{МОРФОМЕТРИЧНА ХАРАКТЕРИСТИКА ПАРАМЕТРІВ ЧЕРЕПА ТА ЛИЦЯ ПЛОДІВ І НОВОНАРОДЖЕНИХ} Слободян О.М., Костюк В.О., Дундюк-Березина С.І.

Сучасна наука володіє значною кількістю діагностичних методів: краніологічних, анатомічних, ультразвукових, рентгенологічних. Розвиток нових методів дослідження, таких як ультразвукові та рентгенологічні методи (магнітно- 
резонансної томографії), формує поняття ультразвукової та рентгенологічної норми на різних етапах розвитку людини. Нині є актуальним вивчення анатомічної мінливості людини, морфометричних характеристик, взаємовідношень органів, анатомічних структур, ї частин на всіх етапах розвитку людини. Мета роботи - встановити нормативні морфометричні параметри черепа і лиця в плодів та новонароджених з наступною побудовою математичних моделей. Дослідження виконано на 57 препаратах плодів людини 4-10 місяців та 7 новонароджених за допомогою адекватних анатомічних методів: макропрепарування, виготовлення топографоанатомічних зрізів, комп'ютерної томографрії, краніометрії. За допомогою сантиметрової стрічки, товстотного, ковзаючого циркулів та итангель-циркуля вимірювали основні параметри лицевого та мозкового черепа. Статистичний аналіз отриманих даних проводили за допомогою ліцензованої програми RStudio. За даними графріків середніх значень параметрів черепа та лиця встановлено два періода прискореного та два періода уповільненого розвитку. Для поперечної довжини черепа, ширини лиця та висоти черепа виявлено два періоди прискореного розвитку з 6-го по 8-й місяці внутрішньоутробного розвитку та з 9-го місяця розвитку до періоду новонародженості і два періода сповільненого розвитку - з 5-го до 6-го місяця та з 8-го до 9-го місяці внутрішньоутробного розвитку. Для загальної висоти лиця - періоди прискореного розвитку - з 4-го по 6-й місяці розвитку та з 7-го до 9-й місяця внутрішньоутробного розвитку, періоди сповільненого розвитку - з 6-го до 7-го місяия розвитку та з 9-го місяия внутрішньоутробного розвитку до періоду новонародженості. На основі середніх арифметичних даних поперечної довжини черепа, ширини лиця, висоти черепа, загальної висоти лиця, побудовані моделі прогнозування нормативних морфометричних їх параметрів у плодів та новонароджених. Побудовані моделі слугуватимуть нормою для наступного визначення певних морфометричних відхилень для встановлення варіантів будови та вад розвитку черепа і лиця. Таким чином, систематизовані нами дані про особливості просторово-часових перетворень морфометричних параметрів поперечної довжини черепа, ширини лиця, висоти черепа, загальної висоти лиия з наступною ї побудовою математичних моделей сприятимуть індивідуалізації норми, удосконаленню методів ранньої діагностики та розробці нових способів хірургічної корекції природжених вад черепа і лиця.

Ключові слова: череп, морфометрія, плід, новонароджений, людина. 